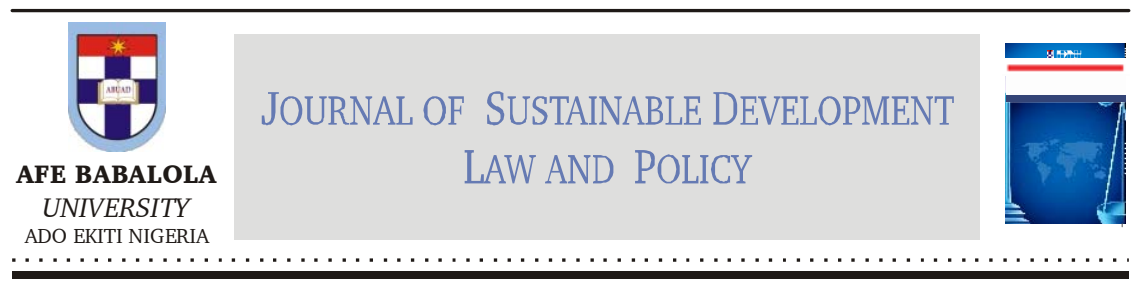

\title{
REGIONAL GAS INTERCONNECTIVITY AND THE IMPLICATIONS OF TRADE IN LIQUIFIED NATURAL GAS FOR ENERGY SECURITY OF NON-EU WESTERN BALKAN STATES
}

\section{ALI OGUZ DIRIOZ* \\ ERAY ERBIL **}

\begin{abstract}
The article examines the state of energy security in the Balkans, the level of regional gas interconnectivity and the role of trade in liquefied natural gas (LNG) in enhancing energy security in the region. The study shows that infrastructure investments are required in the Balkans. However, the small size of the Balkan market lowers investment incentives. In this context, the policy entrepreneurship of the EU Commission can increase solidarity and investments in the Balkans. Moreover, planned and existing pipeline-LNG projects in the periphery of the Balkans can enhance the energy security of these countries.
\end{abstract}

Keywords: Liquefied Natural Gas; Energy Security; the Balkans; European Union.

DOI: https://dx.doi.org/10.4314/jsdlp.v10i2.1

* Assistant Professor, Department of International Entrepreneurship, TOBB ETÜ University, Sögütözü Caddesi No: 43, Sögütözü, Ankara, Turkey. Email: adirioz@etu.edu.tr

** PhD Student, Department of International Relations. Middle East Technical University (METU), Universiteler Mahallesi, Dumlupinar Bulvari No: 1 Çankaya, Ankara, Turkey. Email: erayerbil@etu.edu.tr 


\section{INTRODUCTION}

The global gas industry has been transformed thanks to liquefied natural gas (LNG). LNG has become more and more desirable in the past few decades because of its trade flexibility and its ability to increase energy security. Considering that the European Union and non-European Union (EU) Balkan countries are dependent on gas imports, LNG can enhance the energy security of these countries. However, the distribution of gas among the Balkan countries requires interconnected and developed gas infrastructure. As a result, in this research, the manner in which LNG can secure energy supplies of non-EU Balkan countries and thus enhance regional interconnectivity will be elaborated.

We argue that energy investments cannot be explained purely by economies of scale, due to the small size of the Balkan gas market. Therefore, energy security and the EU's energy strategies of 2020, 2030 and 2050 would complement regional integration aspirations. In this context, we observe that future arguments related to this topic will likely be related to the form of gas supply, such as pipeline or LNG, rather than country of origin. Equally important with the form of supply, we assert that regional interconnectivity is vital for securing energy supplies of the Balkan countries and thus enhancing regional cooperation. Hence, we claim that the desire of Western Balkan countries to comply with the energy and environment strategies of the EU will increase policy entrepreneurship of the EU Commission. This will foster solidarity and thus increase investment incentives.

This article is divided into seven sections. After this introduction, section 2 provides theoretical background on European energy integration. In section 3, the global LNG market, the European gas market, and the Balkan gas market will be assessed in order to understand global and regional gas dynamics. After the assessment of the Balkan gas market, the energy security of the Balkans is discussed in section 4. To enhance energy security, the prospects of LNG in the Balkans and gas interconnectivity in the region are elaborated in section 5. Section 6 also presents a comparative analysis of internal and external advantages and disadvantages is also provided, while section 7 sets out the conclusions.

\section{EUROPEAN ENERGY INTEGRATION: THE THEORETICAL FRAMEWORK}

European integration has a vast literature. For this reason, to understand 
policy and interconnectivity as well as to provide contextual analysis, a brief overview of the theoretical framework is necessary. The European integration and single market objective rely on neo-liberal, particularly institutionalist assumptions (which are relevant for anti-corruption goals, thus facilitating investments). Neo-liberals argue that peaceful cooperation is possible if democracy, economic interdependence, and international organizations exist. ${ }^{1}$ (Swisa, 2011: 130). These three assumptions are key ingredients of European integration since they foster cooperation and reduce corruption and the likelihood of conflict. Besides, funding infrastructure projects through an institutional mechanism enhance interdependence and cooperation between countries.

Political and security considerations as well as seeing the Balkan countries as a part of European identity opened a way for EU membership for these countries. Besides the EU integration and single market literature, Copeland's trade expectations theory asserts that expectations from future trade affect the state's decision to go to war. Current trade between countries can be low or non-existent but positive expectations from the future are vital for the continuity of peace. ${ }^{2}$ Copeland's theory can be interpreted for the Balkans, especially given the history of recent conflicts. Most notably, the break-up of Yugoslavia and ensuing ethnic conflicts across the region (Kosovo, Bosnia, Serbia, North Macedonia, etc.) are important challenges that need to be overcome to establish a basis for regional cooperation and development.

Following the break-up of Yugoslavia in the 1990s, the Balkans were faced with bloody Bosnian and Kosovo wars. Still, these wars have an effect on the current relations between these countries. For instance, relations between Serbia-Albania, Greece-North Macedonia, and GreeceKosovo are fraught with serious issues that need to be addressed. Hence, cooperation and trust-building are not easy to achieve in the region. For gas, the Balkan gas market is small and immature, so there are fewer incentives for investments due to concerns about economic viability. With EU funds, however, these countries can increase interconnectivity with each other as well as with the EU countries. This leads to increasing

1 M. Swisa, "Future Stability in the European Union: Realism, Constructivism, and Institutionalism." Claremont-UC Undergraduate Research Conference on the European Union, vol.1, no. 11, 2011, p. 130.

2 D. C. Copeland, "Economic Interdependence and War: A Theory of Trade Expectations." International Security, 20, 4, 1996, pp. 6-7. 
interdependence, transparency, and creating positive expectations from future economic trade. Moreover, future economic and social integration decreases the likelihood of conflict.

The European Union has been praised for its role in stabilizing Eastern Europe and has received the Nobel Peace Prize as an institution on grounds that it solidified reconciliation, stability, and fraternity in the European continent. $^{3}$ Arguably, the EU is, in practice, displaying features of an international society and solidarity within an institutional collaboration. Such institutional collaboration has binding obligations on its members. This display of institutionalism also conforms with the Kantian ${ }^{4}$ and Grotian traditions of solidarity, as well as solidarity among a community of states. ${ }^{5}$ As part of strong institutional mechanisms, the European Commission monitors and assists member states to increase compliance with the EU laws, policies, and targets. This gives the Commission a role of policy entrepreneur.

The Commission's role as a "policy entrepreneur" is described as its power to take initiatives and to act as an institution that generates ideas prior to policy implementation. The Commission often uses external expertise through seminars, conferences and research groups to have discussions prior to the shaping of new "entrepreneurial" policy initiatives. Thus, the Commission is able to propose new courses of action and policies for adoption by member states, which in turn solidify solidarity and common practice among members. ${ }^{6}$

The Commission's interaction and coordination with all members increase solidarity in the Union since it can influence policymaking in member states, provide solutions during crises and contribute to social construction. ${ }^{7}$ In the context of Balkans, the involvement of the

3 The Nobel Prize, “The Nobel Peace Prize 2012", NobelPrize.org, 12 October 2012, https://www.nobelprize.org/prizes/peace/2012/summary/ (accessed 21 June 2019).

4 In the Perpetual Peace, Immanuel Kant refers to the solidarity among a group of states that constitute a league of peace.

5 W. Bain, "The Pluralist-Solidarist Debate in the English School", Guide to the English School in International Studies, 2013, p.160; Kant, I., "To Perpetual Peace: A Philosophical Sketch", Indianapolis, Hackett Publishing, 2003, p. 14.

6 L. Brigid, "From Policy Entrepreneur to Policy Manager: The Challenge Facing the European Commission", Journal of European Public Policy, vol. 4, no. 3, 2011, pp. 423-424.

7 T. Maltby, "European Union Energy Policy Integration: A case of European Commission Policy Entrepreneurship and Increasing Supranationalism", Energy Policy, vol.55, 2013, pp. 436-437. 
Commission to converge the Balkan countries to the EU laws, policies and targets have the potential to increase solidarity in the region, and thus reduce the likelihood of new conflicts. Therefore, thanks to policy entrepreneurship of the Commission, Western Balkan countries can potentially attract investments.

These future expectations for Western Balkans are insufficient unless they are complemented with the EU integration, social expectations of the EU membership such as transparency and good governance (especially anti-corruption) and the EU's energy strategies. The Balkan market is of little significance at the global and regional levels and it is open for development as indicated in the following parts. In light of this perspective that institutionalism is the driving force behind investment in the Balkan energy security, the article will assess global and regional market developments.

\section{AN ASSESSIMENT OF GLOBAL AND REGIONAL MARKET DEVELOPIMENTS}

\subsection{Global LNG Market}

With the changing gas production and consumption patterns, the natural gas industry has transformed, and LNG has become a little more competitive. In 2018, 943.4 billion cubic meters (bcm) of gas was traded globally of which $431 \mathrm{bcm}$ was LNG. This $431 \mathrm{bcm}$ of LNG accounts for 45.7 per cent of global gas trade. ${ }^{8}$ According to the International Energy Agency (IEA), in 2000, the share of LNG in the global gas trade was only 23 per cent. ${ }^{9}$ This means that the share of LNG has been growing in the international gas trade and has been changing the gas market patterns.

A significant increase in unconventional gas production allowed the U.S. to have a considerable domestic production and decreased gas imports over time. This enabled the United States to become self-sufficient as well as a net gas exporter by 2017. Developments in shale increased the availability of gas around the world, thus decreasing spot gas prices.

8 BP, “BP Statistical Review of World Energy 2019", 12 June 2019, https:// www.bp.com/content/dam/bp/business-sites/en/global/corporate/pdfs/ energy-economics/statistical-review/bp-stats-review-2019-full-report.pdf, accessed 2 August 2019, p. 38.

9 International Energy Agency, Market Report Series: Gas 2017, Paris, OECD Publishing, 2017, p. 91. 
The slightly more flexible trade of LNG makes it preferable to pipeline gas trade for many countries. For instance, the construction of the LNG terminal in Poland completed in 2015 allowed the import of LNG from different producers. In 2017, Poland received its first U.S. LNG, enabling it to reduce its high gas dependency on Russia. ${ }^{10}$ Similarly, in 2016, Lithuanian floating LNG terminal was inaugurated, and the country received its first U.S. LNG in $2017 .{ }^{11}$

LNG allowed these two countries to improve their energy security by increasing alternative sources. Availability of alternatives also gave leverage to these countries to renegotiate gas prices in their long-term gas contracts. Similarly, LNG in the Balkans can foster competition and help these countries to diversify their sources, thus securing their energy supplies. The discourse of energy security in Europe and the Balkans are mostly on gas and least on crude oil.

A major difference between natural gas from petroleum is that gas is less flexible, and spot markets are more regional and represent a small share of the global gas trade. Crude oil, which is more fungible and liquid, thus transported in barrels has the feature of a global commodity market. Also, crude oil has international institutions such as the Organization of the Petroleum Exporting Countries (OPEC) and IEA stocks. Unlike oil, natural gas does not have international institutions. Most resembling institutional cooperation are IEA, EU institutions and smaller institutions such as Energy Charter and Gas Exporting Countries Forum. ${ }^{12}$

LNG, in the long run, could potentially be a game-changer by allowing gas to increasingly become a global market and allow a logistic transportation and trade flexibility very much as it is in the case of oil. However, pipelines and networks are needed to distribute gas to retail markets, considerable infrastructure and installations are necessary to liquefy, transport, and regasify LNG in the supply chain. Therefore, it still would take a lot more of economies of scale to achieve a growing

10 Gawlikowska-Fyk et al. "Germany and Poland in the Energy Union." Hein Online, vol.7, no.49, 2017, p. 53.

11 C. S. Kulander, "European Energy Security, American LNG, and the Global Natural Gas Marketplace." Hein Online, vol.3, no.1, 2017, p. 877.

12 Gas Exporting Countries Forum is an attempt to create OPEC like organization in the field of gas. However, the institution is at a level of a forum, not at an organization level. Since its establishment in 2001, the institution has not been transformed into an organization. 
global spot price market similar to oil. In the meantime, because of the relative inflexibility and high transport and infrastructure costs, LNG, similar to natural gas, is still dominated by mid- and long-term contracts.

According to IEA, global gas demand is expected to rise by 20 per cent between 2016 and 2030 and 14 per cent between 2030 and 2040. ${ }^{13}$ With the increase in liquefaction capacity in Australia, the U.S., Russia, Malaysia, and Indonesia, global liquefaction capacity reached $502 \mathrm{bcm}$ and global regasification reached $1,157 \mathrm{bcm}$ in 2017. In the short run, an additional $130 \mathrm{bcm}$ of liquefaction capacity is expected to come onstream around 2021, contributing to spot market development. ${ }^{14}$ Therefore, we can expect in the near future that an increase in the number of LNG facilities will further decrease LNG import prices, making LNG more attractive than pipelines. Also, liquidity and convenience in the LNG trade undermine new major pipeline projects to be developed (with the exception of those needed for retail and interconnectivity). Owing to the small size of gas markets, population and economies of scale, this is not the case for the Balkans.

Prices in the European market support this prediction. Gas import price by pipeline rose above US\$9.50/MMBtu in 2014 before decreasing to around US\$7.55/MMBtu in 2018. Also, LNG import price for Europe was around US\$8.50/MMBtu in 2014 and later decreased to around US\$7.50/MMBtu in 2018. ${ }^{15}$ This shows that pipeline and LNG prices have become competitive in Europe. Between 2014 and 2017, the average LNG import prices for Japan and Korea dropped from above US\$16/ MMBtu to US\$9.90/MMBtu. In the same years, LNG import prices for the U.S. dropped from US $\$ 8.14 / \mathrm{MMBtu}$ to US $\$ 3.13 / \mathrm{MMBtu}{ }^{16}$ Therefore, these prices suggest that LNG import prices in Europe and Asia are becoming less differentiated and are in a converging trend over the last few years. Furthermore, these trends may lead to a global commodity pricing formulation for natural gas in the long-term.

LNG contracts between 2011 and 2016 show that consumer countries preferred shorter contract periods with smaller volumes, hence less

13 International Energy Agency, World Energy Outlook 2017, Paris, OECD Publishing, 2017, p. 339.

14 SNAM, Global Gas Report 2018, Milan, SNAM, 2018, pp. 16-17.

15 European Commission Directorate-General for Energy, Quarterly Report on European Gas Markets, Brussels, vol.11, no.4, 2019, pp. 21-22.

16 BP, "BP Statistical Review of World Energy 2019", p. 37. 
commitment. ${ }^{17}$ Therefore, gas trade has become more flexible since longterm gas contracts create dependency on energy-producing countries. To ensure the sale of gas in the future, big gas producers such as Russia started to provide flexibilities in pipeline gas contracts, especially regarding take-or-pay clauses. Consequently, new gas contracts started to have a hybrid identity. Hybrid identity is defined as "various forms of supply arrangements - long-term and short-term, large and small, oil-indexed, hub-based and spot - [which] coexist and compete with each other, reflecting the different needs of buyers and sellers alike."18 As shown, global LNG trade dynamics have a direct effect on regional gas trade patterns. Since the main focus of this research is the Balkans, European gas market needs to be assessed.

\subsection{The European Gas Market}

Following an increase in its gas consumption together with the low indigenous gas production, the EU has become a net gas importer in the past decades. In particular, a considerable decline that occurred in certain fields such as Groningen in the Netherlands due to social factors have further accelerated the decline in gas output in the EU. ${ }^{19}$ The 2018 gas demand of the EU was $474 \mathrm{bcm}$ of gas, of which $363 \mathrm{bcm}$ was imported. Gas was imported from Russia (40 per cent), Norway (32 per cent), Algeria and Libya (10 per cent) and LNG (18 per cent). ${ }^{20}$

With the 2006 and 2009 Ukrainian crises, energy security has become one of the priorities for the European Union. Even though the crises were between Russia and Ukraine, gas disruptions had a negative impact on the European countries especially on Central and Eastern Europe, including the Balkans. Diversifying energy sources and routes to ensure and secure the continuous supply of energy became one of the top priorities

17 International Energy Agency, World Energy Outlook 2017, p. 387.

18 International Energy Agency, World Energy Outlook 2017, p. 388.

19 N. Voort, and F. Vanclay, "Social Impacts of Earthquakes Caused by Gas Extraction in the Province of Groningen, The Netherlands.", Environmental Impact Assessment Review, vol.50, 2015, p.11; S. Van den Berg, "The Netherlands to halt gas production at Groningen by 2030", Reuters, 29 March 2018, https://www.reuters.com/article/us-netherlands-groningen-gas/ netherlands-to-halt-gas-production-at-groningen-by-2030-idUSKBN1H51PN, (accessed 18 March 2019).

20 European Commission Directorate-General for Energy, Quarterly Report on European Gas Markets, Brussels, vol.11, no.4, 2019, pp. 2-3. 
in the EU's energy agenda. With the climax of Russian-Ukrainian crises following Russia's annexation of Crimea in 2014, concerns on energy supply security resurfaced as dominant topic of European discourse.

In the aftermath of the 2006 and 2009 Ukrainian crises, the European Union developed 2020, 2030 and 2050 strategies to address energy security issues and to combat climate change. With these strategies, the EU targets to increase the share of renewables by 20 per cent in 2020 and 27 per cent in 2030; increase energy efficiency by 20 per cent in 2020 and 27 per cent in 2030; reduce greenhouse gas emissions by 20 per cent in 2020,40 per cent in 2030 and $80-95$ per cent by 2050 compared to 1990 levels. ${ }^{21}$

Moreover, the EU signed the Paris Agreement which opened for signature in 2016. The agreement aims to reduce greenhouse gas emissions and combat climate change by keeping the global average temperature below $2{ }^{\circ} \mathrm{C}$ compared to pre-industrial levels. ${ }^{22}$ This indicates the EU's strong intention to fight with global warming. All these strategies and targets are monitored and governed by the Commission, showing the Commission's substantial role as a policy entrepreneur. After the set of these strategies, the European countries have increased their reliance on renewables and natural gas. Gas is one of the safest and cleanest alternatives these countries have compared to nuclear energy, coal, or other fossil fuels since gas releases less carbon dioxide to the atmosphere, thus enabling these countries to meet with these standards. ${ }^{23}$ Consequently, in recent years, gas imports of the EU have been increasing.

21 European Commission, “2020 Energy Strategy”, https://ec.europa.eu/energy/ en/topics/energy-strategy-and-energy-union/2020-energy-strategy, (accessed 10 March 2019); European Commission, "2030 Energy Strategy", https:// ec.europa.eu/energy/en/topics/energy-strategy-and-energy-union/2030energy-strategy, accessed (10 March 2019); European Commission, "2050 Energy Strategy", https://ec.europa.eu/energy/en/topics/energy-strategy-andenergy-union/2050-energy-strategy, (accessed 10 March 2019).

22 European Commission, "Paris Agreement", https://ec.europa.eu/clima/ policies/international/negotiations/paris_en, (accessed 10 March 2019).

23 International Gas Union, "Natural Gas is the Cleanest Fossil Fuel", https:// www.igu.org/natural-gas-cleanest-fossil-fuel, (accessed 10 March 2019). 


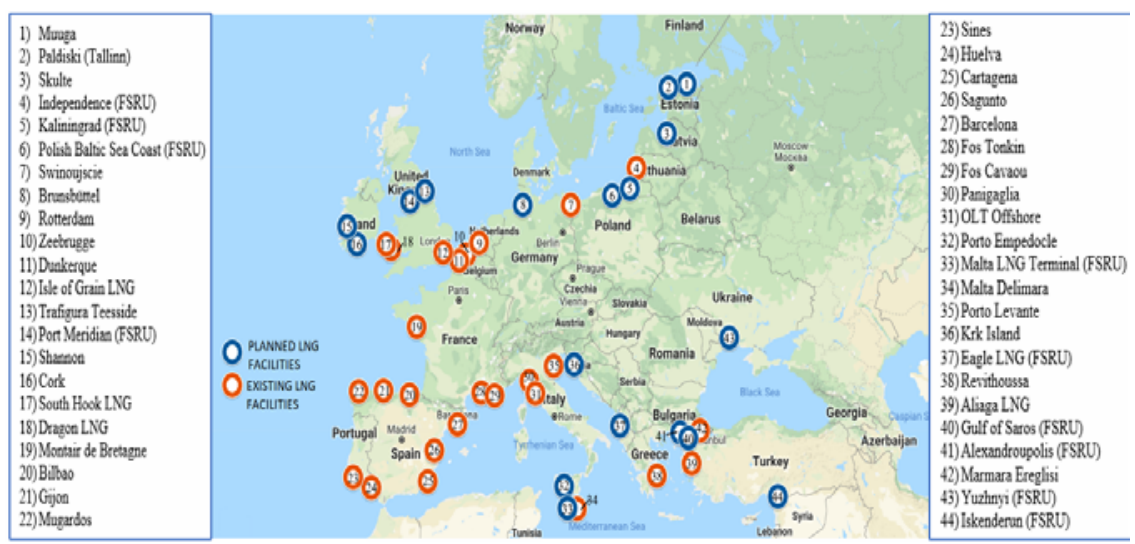

Figure 1: LNG Import Terminals in Europe

Source: Map created by authors using Google Maps and data from Gas Infrastructure Europe.

Among gas imports, although the share of LNG in imports has increased, pipeline gas trade is still dominant in Europe. As shown in (Figure 2), there are 24 LNG facilities owned by 11-member states. The total import capacity of the 24 facilities was $210 \mathrm{bcm}$ in 2017 . With the completion of the planned facilities' constructions, LNG import capacity of the Union will rise to $282 \mathrm{bcm}$ in $2026 .{ }^{24}$ The planned facilities will be in Croatia, Estonia, Germany, Greece, Ireland, Italy, Latvia, Malta, Poland, and the UK. Besides the EU countries, one LNG facility was planned for Albania, one in Ukraine and two in Turkey.

Even though the Union has the ability to cover approximately 43 per cent of its gas demand from LNG,${ }^{25}$ imports from that source remained relatively low. There are two reasons for the underutilization of the LNG facilities. First, hybrid Russian gas contracts make pipeline gas trade

24 Gas Infrastructure Europe, "GLE LNG Investment Database", 2018, https:// www.gie.eu/index.php/gie-publications/databases/lng-investment-database, (accessed 17 April 2019).

25 The number was calculated by authors with using percentage calculation formula. EU gas demand and import capacity data which was given in the article was used. 
more attractive. In addition, selling its gas below spot prices have made Russian gas competitive compared to LNG. For instance, in 2017, Russian gas sold at around US\$5.9/MMBtu while European spot prices were around US\$6.2/MMBtu (Henderson et al. 2018: 4). Secondly, high gas prices in the Asian market led LNG ships to be diverted to Asian countries. Therefore, Russia's ability to make price dumping and supply a vast amount of gas thanks to its geographical proximity made the European market less attractive in the eyes of LNG producing countries. Weighed against the European scale, Balkans gas potentials holds but small significance. Next, we look at the Balkan gas market as a regional market integration prospect.

\subsection{Balkan Gas Market}

The discussion of energy security for the EU dates back to Central and Eastern enlargement of 2004 and 2007. Gas infrastructure and market dynamics of Central and Eastern European countries are behind those of Western Europe. The latter countries have developed gas infrastructure, competitive and liberal markets, and gas is priced according to hub prices due to competition. ${ }^{26}$ (Jirušek et al 2017: 336). With the EU as an anchor, some Central and Eastern countries, including the Balkans, have made some progress. Since there is no gas trading hub for the Balkan countries, gas is traded based on the bilateral agreements and these countries do not have alternative gas supplies. In the following decades, Italy and Greece could aspire to become physical centres of gas distribution for the Balkans. The Balkan countries even do not have access to LNG, except through Greece which has $5 \mathrm{bcm}$ capacity in the Revithoussa LNG terminal. ${ }^{27}$ Therefore, Russia is currently the sole gas supplier for these countries. However, this situation is likely to change with the realization of new LNG and pipeline projects in neighbouring EU Balkan and Adriatic countries.

26 M. Jirušek, T. Vlèek, and J. Henderson, "Russia's Energy Relations in Southeastern Europe: An Analysis of Motives in Bulgaria and Greece." PostSoviet Affairs, vol.33, no.5, 2017, p. 336.

27 S. Elliott, "New Greek LNG Project FID Slips to Late 2018", S\&P Global Platts, 19 February 2018, https://www.platts.com/latest-news/natural-gas/london/ new-greek-lng-project-fid-slips-to-late-2018-26894120 (accessed 13 May 2019). 
Table 1: Economic and Social Indicators of Non-EU Balkan Countries

\begin{tabular}{|c|c|c|c|c|}
\hline \multicolumn{3}{|c|}{ Economic and Social Indicators of Non-EU Balkan Countries (2018) } \\
\hline Countries & Population & GDP (Billion \$) & GDP Per Capita (\$) & $\begin{array}{c}\text { Foreign } \\
\text { Direct } \\
\text { Investment } \\
\text { Net Inflow } \\
\text { (Billion \$) }\end{array}$ \\
\hline Albania & $2,866,376$ & 15,059 & 5,253 & 1,207 \\
\hline $\begin{array}{c}\text { Bosnia and } \\
\text { Herzegovina }\end{array}$ & $3,323,929$ & 19,782 & 5,951 & 0,485 \\
\hline $\begin{array}{c}\text { North } \\
\text { Macedonia }\end{array}$ & $2,082,958$ & 12,672 & 6,083 & 0,674 \\
\hline Kosovo & $1,845,300$ & 7,900 & 4,281 & 0,240 \\
\hline Montenegro & 622,345 & 5,452 & 8,760 & 0,485 \\
\hline Serbia & $6,982,084$ & 50,508 & 7,233 & 4,107 \\
\hline
\end{tabular}

Source: World Bank.

The main reason impeding the Balkan countries from reaching LNG is that many of them, especially the non-EU Balkan countries, are not major markets, thus in economic terms, they are not very attractive to investors. As can be seen in Table 1, not much Foreign Direct Investments have been made to these countries. Moreover, the relatively small populations of these countries reduce the likelihood to attract substantial investments for infrastructure.

The Balkan countries also do not have robust and connected gas infrastructure for bringing LNG from Greece. Hence, these countries are over-dependent on a single supplier and are thus vulnerable to gas supply disruptions. Being the sole supplier enables Russia to negotiate bilaterally and to charge higher gas prices than hubs apart from sometimes using the commodity as political leverage as some observers have alleged. As a result, the Union has focused on providing energy-related solutions to the Southern European countries.

In 2014, the EU released the Energy Security Strategy in response to concerns over gas disruptions. In the short-term, the Union developed and simulated two scenarios. The first pictured a complete cessation of Russian gas and the second focused on gas disruptions in Ukraine transit route. The results of the simulations suggested that long supply disruptions would have a significant effect on Southeastern EU countries as well as the Energy Community countries. ${ }^{28}$ In the long term, five key

28 European Commission, "Energy Security Strategy", https://ec.europa.eu/ energy/en/topics/energy-strategy-and-energy-union/energy-security-strategy, (accessed 28 May 2019). 
action points were identified for addressing the security of energy supply: (i) Increasing energy efficiency; (ii) Increasing energy production and diversifying supplier countries and routes; (iii) Completing the internal energy market; (iv) Speaking with one voice; (v) Strengthening emergency and solidarity mechanisms. ${ }^{29}$ For our research, the second, third and fifth action points are the most relevant for non-EU Balkans. In a London Summit on the Western Balkans in 2018, the EU openly committed to expanding cooperation with Western Balkan countries in the areas of economy and security. ${ }^{30}$ This is in line with the policy of interconnectivity with surrounding EU member states for electricity and gas markets among other things. Moreover, an increase in cooperation between the EU and the Balkan countries will foster the entrepreneurship policy of the Commission, which is vital for increasing solidarity as well as attracting investments.

To support infrastructure projects and ensure the security of supply, the EU formed Projects of Common Interest (PCI). These projects are generally composed of construction and infrastructure improvements, potentially including pipelines, interconnectors, reverse flow technologies, gas storages, LNG terminals, and compressors. ${ }^{31}$ The PCI helps member states to develop their infrastructure and increase interconnectivity with each other, and secure energy supply by deepening cooperation. Projects that received funding from PCI include the feasibility studies of Eastring pipeline and LNG facilities in Greece and Croatia, as well as the construction of interconnector Greece- Bulgaria. ${ }^{32}$

The EU allocated $\bullet 5.35$ billion to fund the PCIs between 2014 and $2020 .^{33}$ The Energy Community provides EU funds to these countries, so that missing infrastructure between EU and non-EU countries can be built. All these suggest that economic investments alone cannot sufficiently account for energy investments in the Balkans. As argued in

29 European Commission, "Energy Security Strategy".

30 European Union External Action Service, "Mogherini on Western Balkans: Shared Commitment towards Our Common Future", 10 July 2018, https:// eeas.europa.eu/headquarters/headquarters-homepage_en/48215/Mogherini\% 20on\%20Western\%20Balkans:\%20Shared\%20commitment $\% 20$ towards\% 20our\%20common\%20future, (accessed 12 June 2019).

31 European Commission, "Funding for Projects of Common Interest.", https:// ec.europa.eu/energy/en/topics/infrastructure/projects-common-interest/ funding-projects-common-interest, (accessed 2 May 2019).

32 European Commission, "Funding for Projects of Common Interest."

33 European Commission, "Funding for Projects of Common Interest." 
the part below, institutional cooperation to invest in energy security would be a stronger motive. That will provide investment incentives.

\section{ENERGY SECURITY OF THE BALKAN COUNTRIES}

Established in 2006, the Energy Community is a tool of the EU for integrating energy markets and laws of the EU neighbouring countries with the EU energy market and law, hence increasing energy security and regional cooperation. ${ }^{34}$ Currently, non-EU Balkan states have different status on the EU membership track. ${ }^{35}$ Bosnia \& Herzegovina became a candidate country in 2003, North Macedonia in 2005, Montenegro in 2010, Serbia in 2012, Albania in 2014 and Kosovo 2008. ${ }^{36}$ Energy Community provides EU funds and grants to its members and in return, it expects compliance with the EU energy laws, policies, and regulations. 2018 budget of Energy Community was $\bullet 4.76$ billion since it includes Western Balkan countries as well as Ukraine, Moldova and Georgia. ${ }^{37}$ Therefore, EU funds have an important place for the Balkans in the way of development of interconnectivity and interdependence as well as to implement EU strategies of 2020, 2030 and 2050 to combat climate change.

To become an EU member, these countries need to fulfil the Copenhagen criteria and approximate their laws to the EU law. In this context, the reforms adopted under the Energy Community directly benefits the membership status of the Balkan states. ${ }^{38}$ In 2014, Western

34 Energy Community, "Who We Are", Energy Community, 2018, https:// www.energy-community.org/aboutus/whoweare.html, (accessed 21 June 2019).

35 Turkey's membership candidate status is much older and more complicated than the other Western Balkan Initiative countries. Hence it is too detailed to be covered within the scope of this research. Turkey is observer to Energy Community, hence no access to its funds.

36 European Union Newsroom, "EU Enlargement-State of Play", https:// europa.eu/newsroom/highlights/special-coverage/enlargement_en, (accessed 21 May 2019).

37 Energy Community, "Budget at a Glance", https://www.energy-community.org/ aboutus/budget.html, (accessed 21 May 2019).

38 Energy Community, "Knocking on the EU's Door through the Energy Community: Integration of Western Balkans into the Pan-European Energy Market", 6 February 2018, p.9, https://www.energy-community.org/dam/ jcr:f28990a7-1d9e-44a5-9e1d-db1d57187403/EnC_WB6Report_012018.pdf, (accessed 14 June 2019). 
Balkan 6 Initiative (WB6) was launched under the Energy Community umbrella to assist Albania, Bosnia \& Herzegovina, Kosovo, North Macedonia, Montenegro and Serbia for developing and integrating energy ties, infrastructures and markets of these countries also assisting to overcome challenges in transparency and anti-corruption. ${ }^{39}$ With the EU's single energy market objective, gas can be shared between the member states, making the EU and the Balkans part of a more interconnected market, making smaller states less vulnerable.

Table 2: Natural Gas Production, Consumption, And Trade of Non-EU Balkan Countries

\begin{tabular}{|c|c|c|c|c|c|c|c|c|c|c|c|c|c|c|c|}
\hline & \multicolumn{5}{|c|}{ Production (Mtoe) } & \multicolumn{5}{|c|}{ Consumption (Mtoe) } & \multicolumn{5}{|c|}{ Net Natural Gas Trade (Mtoe) } \\
\hline & 2012 & 2013 & 2014 & 2015 & 2016 & 2012 & 2013 & 2014 & 2015 & 2016 & 2012 & 2013 & 2014 & 2015 & 2016 \\
\hline Albania & 0,01 & 0,01 & 0,02 & 0,03 & 0,03 & 0,01 & 0,01 & 0,02 & 0,03 & 0,03 & 0,00 & 0,00 & 0,00 & 0,00 & 0,00 \\
\hline Bosnia and Herzegovina & 0,00 & 0,00 & 0,00 & 0,00 & 0,00 & 0,21 & 0,16 & 0,15 & 0,18 & 0,18 & 0,21 & 0,16 & 0,15 & 0,18 & 0,18 \\
\hline North Macedonia & 0,00 & 0,00 & 0,00 & 0,00 & 0,00 & 0,11 & 0,13 & 0,11 & 0,11 & 0,18 & 0,11 & 0,13 & 0,11 & 0,11 & 0,18 \\
\hline Kosovo & 0,00 & 0,00 & 0,00 & 0,00 & 0,00 & 0,00 & 0,00 & 0,00 & 0,00 & 0,00 & 0,00 & 0,00 & 0,00 & 0,00 & 0,00 \\
\hline Montenegro & 0,00 & 0,00 & 0,00 & 0,00 & 0,00 & 0,00 & 0,00 & 0,00 & 0,00 & 0,00 & 0,00 & 0,00 & 0,00 & 0,00 & 0,00 \\
\hline Serbia & 0,42 & 0,42 & 0,44 & 0,46 & 0,42 & 1,68 & 1,87 & 1,61 & 1,75 & 1,89 & 1,43 & 1,50 & 1,11 & 1,39 & 1,43 \\
\hline
\end{tabular}

Source: International Energy Agency.

As shown in Table 2, Kosovo and Montenegro do not use natural gas, and Albania consumes what it produces. Therefore, these three countries do not import any gas. Bosnia \& Herzegovina and North Macedonia are totally dependent on gas imports because of a lack of indigenous gas production. Serbia has low indigenous production and imports most of its gas. These three countries import all of their gas from Russia. In 2016, the total gas production of these six countries was around $0.5 \mathrm{bcm}$, total gas consumption was around $2.5 \mathrm{bcm}$ and total net gas import was around $2 \mathrm{bcm}$, thus showing the small size of the Balkan market.

With the realization of new pipelines such as Trans Adriatic Pipeline (TAP) $(10 \mathrm{bcm})$, and if realized the Ionian Adriatic Pipeline (IAP) ( $5 \mathrm{bcm}$ ) and Eastring Pipeline (20-40 bcm), ${ }^{40}$ Azeri gas can be delivered not only to EU Balkan states such as Greece, Bulgaria, Romania, and

39 Energy Community, "Knocking on the EU's Door", p. 1.

40 Institute of Energy for Southeast Europe, Southeast Europe Energy Outlook 2016/17, Athens, IENE, 2017, p.789; L. Karch and A. Varga, "New European Pipeline Project Eastring", The Holistic Approach to Environment, vol.8, no.1, 2018, pp. 17-19. 
Croatia but also to these non-EU Balkan countries. Thus, these pipelines can enhance integrity and interconnection between non-EU and EU Balkan states. Besides, planned LNG facilities in the Balkans will further strengthen the interconnection and energy security in the region. However, Russian and Azeri gas most likely to reduce short to medium term LNG prospects in the Balkans, so the Balkan countries likely to continue their reliance on pipeline bound gas. The delay of LNG in the region is due to the need for clarity in the European gas market and Russia's long-term gas pricing strategies in respect to U.S. shale developments. ${ }^{41}$ The difficulty in attracting investments to increase interconnectivity is the small population and economy of the combined Balkan countries. Thus, there are fewer incentives by outside and infrastructure projects are difficult to implement. Hence, this relates back to why trade expectations or purely economic investment rationale would not be sufficient but only be complementary to understand approaches dealing with institutional cooperation.

Southern Gas Corridor is one of the top priority corridors for the EU since the corridor serves for the diversification efforts of the Union. The corridor consists of several projects including pipelines and LNG terminals. It aims to enhance the security of supply of Balkan countries, facilitate competition and diversify gas supplies by bringing gas from different regions such as the Middle East, the Caspian and the Mediterranean. ${ }^{42}$

When Azerbaijan started negotiations with the buyers in 2010 before supplying its gas over Trans Anatolian Pipeline (TANAP) (16 bcm), ${ }^{43}$ gas prices in Italy were around 23 per cent higher compared to gas prices in the Balkan countries. For this reason, Azerbaijan targeted to supply its gas firstly to the Italian market. ${ }^{44}$ However, the country also considers supplying its gas to the Balkan market in the future. Besides gas prices,

41 J. Roberts, "Regional Energy Cooperation along Europe's Southern Energy Corridor." The South Caucasus-Security, Energy and Europeanization, Routledge, 2017, p. 206.

42 European Commission, "Gas and Oil Supply Routes”, https://ec.europa.eu/ energy/en/topics/imports-and-secure-supplies/gas-and-oil-supply-routes, (accessed 15 June 2019).

43 Institute of Energy for Southeast Europe, p. 1121.

44 G. Rzayeva, "The Outlook for Azerbaijani Gas Supplies to Europe: Challenges and Perspectives." The Oxford Institute for Energy Studies, 2018, p.27, https:/ /www.oxfordenergy.org/wpcms/wp-content/uploads/2015/06/NG-97.pdf, (accessed 26 June 2019). 
currently the Balkan markets are very small and premature, and therefore these markets are commercially less profitable for Azerbaijan. Therefore, the additional supply of Azeri gas is dependent on the capacity improvements in TANAP and TAP as well as favourable market conditions in the Balkans. Another importance of these two pipelines (TANAP and TAP) is that they can contribute to Italy's and Greece's aspirations to become a Mediterranean gas hub.

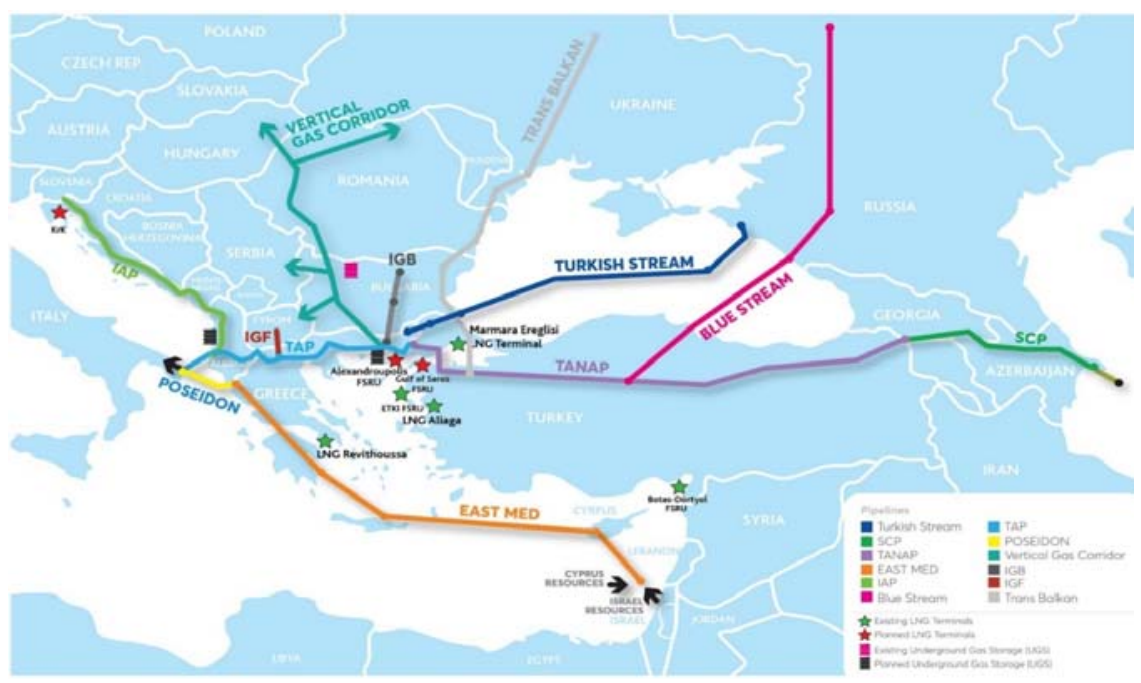

Figure 3: An Expanded Southern Gas Corridor

Source: Institute of Energy for Southeast Europe.

Besides regional projects, Eastern Mediterranean Pipeline (EMP) (10 $\mathrm{bcm}$ ) is the longest planned pipeline in the region that starts in Israel, passes the island of Cyprus, through Greece and ends in Italy. ${ }^{45}$ Considering the low capacities of discovered gas deposits in Cyprus and Israel in respect to gas demand of Europe, such a long underwater pipeline construction is currently not be economically viable. Furthermore, disputes over exclusive economic zones (EEZ) between Turkey and Greek Cypriot government are other major obstacles for the realization of the pipeline. Competition over resources has the risk to impede regional cooperation and stability of Turkish-Greek relations, which are relevant

45 Institute of Energy for Southeast Europe, p. 910. 
for the transit of energy to the Balkans. Eastern Mediterranean energy play could have an effect on energy security of the Balkans. However, its effects remain to be seen in the future.

In order to protect its market domination in the Balkans and to bypass Ukraine transit route after two Ukrainian crises, Russia developed a new pipeline called Turkish Stream. The pipeline would be a direct pipeline between Turkey and Russia, and it will have $31.5 \mathrm{bcm}$ gas capacity. ${ }^{46}$ Even though Russia targeted to supply its gas to TAP, the pipeline granted an exemption of third-party accession from the EU. Therefore, only Azeri gas can be supplied over TAP ${ }^{47}$ If the capacity of the pipeline is expanded, then Russia can supply its gas through that pipeline since expanded capacity does not have an exemption under the EU's energy regulations. However, if Russia books the additional capacity of TAP, this would jeopardize non-Russian suppliers since Russia would dominate Southern Gas Corridor via TAP and Turkish Stream. ${ }^{48}$ In the current context, Russia can supply its gas through the Trans-Balkan pipeline by reversing the pipeline, interconnector Turkey- Greece and planned Eastring pipeline. Besides dominating regional pipelines, Russia also has an ambition to create a regional gas hub in the Southeastern part of the Europe.

In recent years, several energy agreements have been signed between Russia and Serbia; hence Russian investments in Serbia have grown significantly. ${ }^{49}$ One of the reasons for these investments can be linked to the desire of Russia to make Serbia a Russian gas hub in that region to distribute its gas to the neighbouring countries. As indicated in Table 1, among the Balkan countries, Serbia is on the lead in terms of attracting investments, population, and economy. Therefore, this is a theoretically convenient arrangement for Serbia; and Germany provides an example of this situation in the EU. Indeed, Germany insists on ensuring the continuity of the supply through Russian gas, whereas Poland and

46 S. Kýsacýk and F. Kaya “Turkey's Unique Energy Corridor Role at the Center of Eurasia in the 21st Century", Marmara University Journal of Political Science (Special Issue), vol.5, 2017, pp. 97-99.

47 M. Siddi, "The EU's Botched Geopolitical Approach to External Energy Policy: The Case of the Southern Gas Corridor.", Geopolitics, 2017, p. 12.

48 Roberts, "Regional Energy Cooperation", p. 208.

49 J. S. Willemaers, "The Balkans - A Gas Hub in Eastern Europe?", Institut Thomas More, 2014, p.10, http://institut-thomas-more.org/wp-content/ uploads/2017/05/TribuneITM41.pdf (accessed 12 June 2019). 
Lithuania favour LNG. Similarly, LNG can also be considered as a possible alternative form of supplies for the Balkans.

\subsection{LNG in the Balkans}

As shown in (Figure 3), planned LNG facilities in Croatia (4-6 bcm), Greece $(6 \mathrm{bcm})$, and Albania $(4-8 \mathrm{bcm})$ are designed to increase the availability of gas supplies in the region. ${ }^{50}$ These three facilities will have a significant contribution to LNG trade and distribution of gas in the Balkans. However, for the LNG facility in Croatia, there are concerns about objections by the local population, meanwhile importing Russian gas through pipelines would be more cost-effective than importing LNG. Furthermore, there are concerns about the financial sustainability of the project. Therefore, economic viability considerations are slowing the project in Croatia in spite of EU funding. ${ }^{51}$ Cheap and abundant Russian gas led Greece and Albania to postpone their planned LNG projects, which causes the Balkan countries to miss the opportunity of LNG.

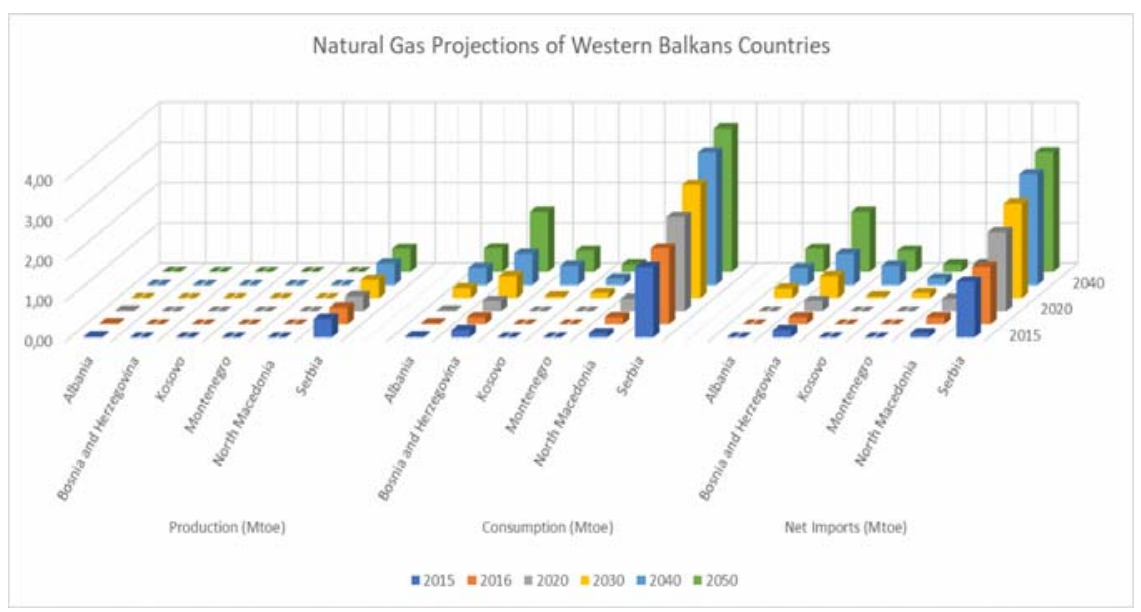

Figure 4: Natural Gas Projections of Western Balkan Countries

Source: International Energy Agency and Institute of Energy for Southeast Europe.

50 Institute of Energy for Southeast Europe 2017, pp. 1076-1077.

51 A. M. Boramisa, "Energy Transition in Croatia - Moving towards Effective Membership in The Energy Union", POLO-Cro28 Policy Paper (Zagreb, Institute for Development and International Relations), 2018, pp. 18-19. 
According to Table 2, the gas demand of six Balkan countries will be around $3.2 \mathrm{bcm}$ in 2020 and around $6.3 \mathrm{bcm}$ in 2040. Considering that the total capacity of four LNG facilities will be over $15 \mathrm{bcm}$ of gas, LNG can be a game-changer in the region. To be more precise, including the EU member Balkan states, total gas consumption of 10 Balkan countries was around $21.6 \mathrm{bcm}$ and total natural gas trade was around $10.8 \mathrm{bcm}$ in 2016. Thus, it is expected that total gas consumption of 10 countries will be around $24 \mathrm{bcm}$ in 2020 and around $26 \mathrm{bcm}$ in 2040, while total gas trade will be around $11.6 \mathrm{bcm}$ in 2020 and around $15 \mathrm{bcm}$ in 2040 . Therefore, LNG could cover more than 70 per cent gas consumption of these countries which would secure the energy supplies of these countries.

At present, cheaper Russian gas erodes plans of the Balkan countries to import LNG. This is because when importing LNG seems costly than importing Russian gas, planned LNG facilities lose their financial feasibility and have difficulties in attracting investments. In fact, the Balkan gas and spot markets are immature and small. Besides, LNG still requires long-term customer commitments and oil-indexed prices show similarities with pipeline gas trade. Building LNG facilities are not enough to enhance energy security of the region. One way to distribute LNG between the Balkan countries is to boost gas interconnectivity. Consequently, the next section will cover gas interconnections in the Balkans.

\section{ENHANCING ENERGY SECURITY THROUGH GAS INTERCONNECTIVITY IN THE BALKANS}

The European Union gives importance to the interconnections between the EU countries as well as between EU and non-EU countries. With the development of gas interconnectivity, the EU envisages gas markets to be united. Once gas enters from the EU borders, European countries will be able to share gas with each other inside the Union. Therefore, countries will be able to access multiple gas sources and regional gas prices will be eventually less differentiated. ${ }^{52}$

As shown in (Figure 4), Balkan interconnections are not well connected. With the realization of the new interconnectors, the Balkan

52 T. Bros, "European Gas Markets: Key Trends", The Oxford Institute for Energy Studies, 2017, p.9, https://www.oxfordenergy.org/wpcms/wp-content/ uploads/2017/09/European-Gas-Markets-Key-Trends.pdf (accessed 16 June 2019). 
countries will be able to share gas coming from pipelines and LNG with each other, and their gas infrastructure will be connected. Since these interconnectors can be compatible with existing and planned pipelines, energy security in the Balkans will be enhanced to a greater degree. As noted above, Greece currently has one operational LNG facility. With these interconnectors, the country can distribute imported LNG to other Balkan countries. This also applies to planned LNG facilities in Croatia and Albania.

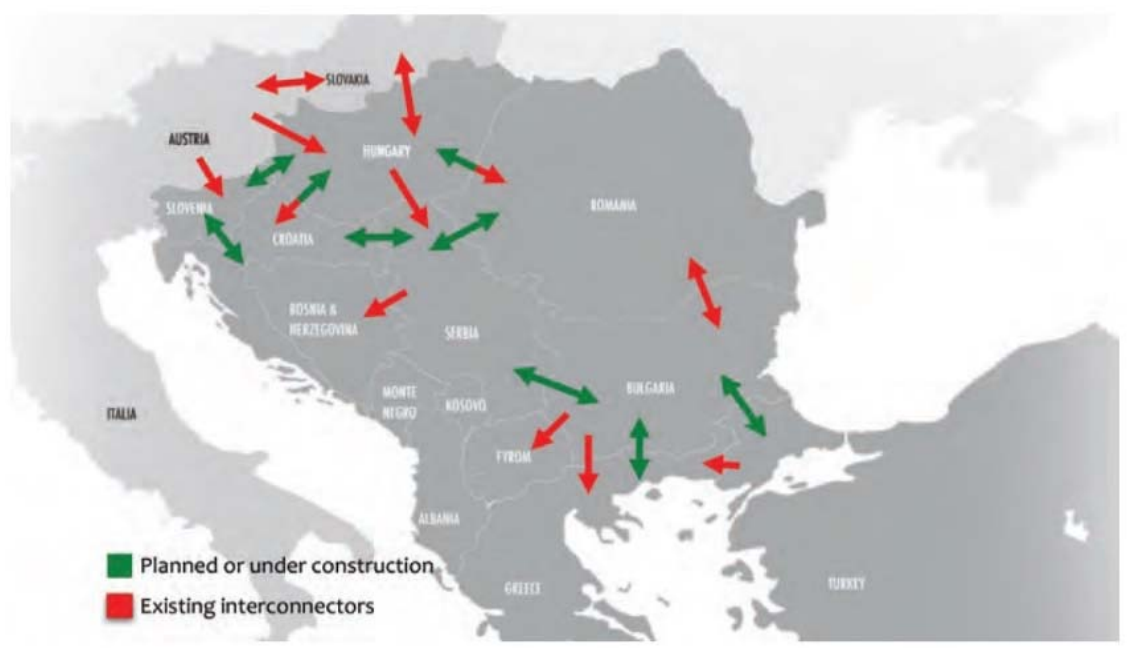

Figure 5: Planned, Under Construction and Existing Interconnectors

Source: Institute of Energy for Southeast Europe.

Besides, seaports and interconnectors, it is possible for the Balkan countries to benefit from existing transportation infrastructure to share LNG between them. Transportation of LNG is possible with the railroads in the region, and it is possible with ships and inland ports in Danube and Sava Rivers. ${ }^{53}$ To stimulate economic growth, export and form Pan-

53 A. Kovacevic, "Towards a Balkan Gas Hub: The Interplay between Pipeline Gas, LNG and Renewable Energy in South East Europe", The Oxford Institute for Energy Studies, 2017, p.34, https://www.oxfordenergy.org/wpcms/wpcontent/uploads/2017/02/Towards-a-Balkan-gas-hub-NG-115.pdf (accessed 16 October 2019). 
European corridor, the EU has made significant investments to the railway infrastructure of the Balkans. With the EU funds, Serbia has built new railroads while Albania, Macedonia, Montenegro and Kosovo have rehabilitated its existing railroads. ${ }^{54}$ Therefore, railways are alternative to pipelines and interconnectors that can secure energy supplies of the Balkan countries. Besides, road transportation is another alternative for the Balkan countries to access LNG.

Danube River, the second biggest river in Europe, is bound to play a useful role in this transportation plan because as many as ten countries (Germany, Austria, Slovakia, Hungary, Croatia, Serbia, Bulgaria, Romania, Moldova and Ukraine) share the river. These countries have 94 ports on the river and 31 of them have the capability to receive liquid cargo. ${ }^{55} \mathrm{All}$ these ten countries have at least one port to handle that type of cargo. Sava is another river in Europe that crosses Slovenia, Croatia, Bosnia \& Herzegovina and Serbia. ${ }^{56}$ Together with railways, carrying LNG on these two rivers will enhance interdependence between the Balkan countries which is vital for stability and cooperation in the region.

Together with inland ports, railways and roads, the use of smallscale LNG (ssLNG) have a potential to secure energy supplies of the Balkan countries. SsLNG is contrary to traditional LNG. SsLNG is used in its liquid form mostly as marine fuel, fuel for road transportation and off grid power generation. It is an innovative solution for immature and small gas markets like the Balkans. This is because its capacity can be increased, and it is flexible to deal with demand fluctuations. ${ }^{57}$ However, some factors determine the investments on ssLNG, including demand, business model and alternative fuel prices. ${ }^{58}$ Therefore, it is a developing trend that can be applicable to the Balkans.

54 B. Pekic, "European Funds Drive Balkan Railway Renaissance", International Railway Journal, 20 January 2019, https://www.railjournal.com/in_depth/ european-funds-drive-balkan-railway-renaissance (accessed 23 Nov 2019).

55 Danube Commission, "Danube Navigation", Danube Commission, 2019, https:/ /www.danubecommission.org/dc/en/danube-navigation/ports-on-thedanube/ (accessed 21 Nov 2019).

56 International Sava River Basin Commission, "About Basin", International Sava River Basin Commission, 2019, https://www.savacommission.org/basin_about (accessed 21 Nov 2019).

57 G. Biscardini, R. Schmill and A. Maestro, "Why Small-Scale LNG May Be the Next Big Wave", PWC, 2017, https://www.strategyand.pwc.com/fr/fr/media/ small-going-big.pdf (accessed 10 Oct. 2019).

58 S. Karbuz, "Küçük, minik, minnacýk ölçekli LNG”, PetroTürk, 25 Sep. 2019, http://petroturk.com/gaspower/kucuk-minik-minnacik-olcekli-lng (accessed 10 Oct. 2019). 


\section{COMPARATIVE ANALYSIS OF INTERNAL AND EXTERNAL ADVANTAGES AND DISADVANTAGES}

In making a comparison of the internal and external factors associated with gas trade, it is easy to identify certain advantages and disadvantages. There are various internal/external and advantages/disadvantages for non-EU Western Balkan countries. The combination of these factors is critical for the future of the energy security of the Balkan countries as well as the EU.

Table 3: Comparative Analysis of Internal and External Advantages and Disadvantages

\begin{tabular}{|c|c|c|}
\hline & \multicolumn{2}{|c|}{$\begin{array}{l}\text { Comparative Analysis of Internal and External Advantages and Disadvantages of } \\
\text { Western Balkans }\end{array}$} \\
\hline & Internal & External \\
\hline Advantages & $\begin{array}{l}\text { Having a cultural and geographical } \\
\text { proximity to Western Europe }\end{array}$ & $\begin{array}{c}\text { The EU membership, the EU funds, } \\
\text { envisaged pipeline projects in the region, } \\
\text { NATO membership of some regional } \\
\text { countries }\end{array}$ \\
\hline Disadvantages & $\begin{array}{l}\text { Having a small population, small } \\
\text { economies of scale, premature gas markets } \\
\text { and less attractive for Foreign Direct } \\
\text { Investments }\end{array}$ & $\begin{array}{c}\text { High dependency on Russian gas,low } \\
\text { infrastructure and interconnectivity, the } \\
\text { possibility of existing and planned pipelines } \\
\text { to postpone LNG projects in the region }\end{array}$ \\
\hline
\end{tabular}

Source: The table is original contribution of the authors.

As an internal advantage, the Balkan countries have cultural and geographical proximity to Western Europe which enables them to establish good relations with the European countries. On the contrary, having a small population, small economies of scale, premature gas markets and less attraction for Foreign Direct Investments can be considered an internal disadvantage for the Balkan countries. These factors directly affect investments in the region.

The EU membership, funds and envisaged pipeline projects in the region are external advantages for the Balkan countries. The EU membership and its funds help these countries to approximate themselves to the EU standards and to develop their infrastructure and interconnectivity. The more interaction and engagement between Western Balkan countries and the EU in the context of the EU membership, the greater the possibility of these countries to attract investments from the 
EU as well as European companies. Besides the EU membership, Albania and Montenegro are NATO members while North Macedonia is likely to join NATO, which suggests close ties of some Balkan countries with the West. ${ }^{59}$ Secondly, envisaged pipeline projects are vital for the improvement of energy security of the Balkan countries. In fact, the Southern Gas Corridor is essential for the EU as a means of securing its energy supplies. Therefore, stability and cooperation in the Balkans will directly contribute to the energy security of the EU. On the contrary, as an external disadvantage, these countries are already highly dependent on Russian gas; they have low infrastructure and interconnectivity and envisaged pipeline projects are likely to postpone LNG projects in the region. The combination of pipeline and LNG projects in the region will highly secure energy supplies of the Balkan and the EU countries. However, cheap Russian gas combined with the prospectus Azeri gas coming over TANAP and TAP may likely to delay LNG projects.

\section{CONCLUSION}

Energy security in the Balkan countries has faced challenges and uncertainties because of low interconnectivity between them. Thus, there is a need for investments in the Balkans. The Balkan market is open to greenfield investments and developments. There are major gas projects in and around the region such as TANAP, TAP, IAP, Eastring pipeline, EMP and Turkish Stream. Ongoing major project nearby creates certain expectations and possibilities for Western Balkans. However, due to the small scale of the Western Balkan market, trade expectations and simple economic interdependence may not be sufficient motives to further investment in this region. In this context, institutional cooperation (EU integration) would complement the regional aspirations to increase energy security but because the regional market is small, the question comes in the form of supply, not in the source of supply. Institutional cooperation, as well as the EU rules, regulations, standards and funds may help improve suitability for potential investments. Policy entrepreneurship of the Commission will also have a distinct role in increasing solidarity and investments.

59 J. Bugajski, "NATO Is More Than Just a Security Organization", 11 February 2019, https://www.cepa.org/nato-secures-the-western-balkans (accessed 15 July 2019). 
The increase in reliance on pipeline or LNG in the Balkans is dependent and will be shaped by the global LNG market, geostrategic context of the Eastern Mediterranean region, clarities related to European gas market and Russia's gas pricing strategies in respect to U.S. shale developments. In this regard, the gas supplied via pipelines will likely dominate the Balkans for quite some time which will reduce the shortto medium-term LNG prospects in the Balkans. With the EU funds and motivations, such as increasing energy security, environmental protection, and good governance, energy infrastructure can be strengthened between non-EU and EU Balkan countries. Good governance and anti-corruption would further help these countries' ability to attracting private investments in addition to EU funds and incentives. However, at the end of the day, economic viability has the last say on infrastructure investments.

Greece and Italy are potential candidates for Balkan gas hub in the case of integrity of existing and planned projects in the region. Greece has strong ambitions to distribute gas coming via TANAP, TAP and Turkish Stream while Italy is the other candidate due to its developed gas market and infrastructure. A suggested future research topic exploring which hub(s) will be dominant (Italy, Greece, Turkey, Serbia, etc.) would help understand future infrastructure serving the sub-region of the Balkans in general and particularly for non-EU Balkans.

Finally, the realization of hubs in the region will be shaped by economies of scale to attract significant investments, and possibly by EU membership. This article argued that the EU, which gave a new perspective for membership to the states of the Western the Balkans, is also the main catalyst for those countries to realize infrastructure investments to consolidate their energy security. Moreover, since these countries, even when combined, constitute a small market, investments are more likely to be realized by EU funds, entrepreneurship and regulations solidifying the confidence of investors to these economies. 